\title{
Traffics of the Sacred and the Secular: Christianity and Citizenship in Asia
}

\section{Introduction}

\author{
Sin Wen Lau | ORCID: 0000-0002-3138-9931 \\ University of Otago, Dunedin, New Zealand \\ sinwen.lau@otago.ac.nz
}

Christianity in Asia, particularly its relationship with the state, offers an important counterpoint to studies of global Christianity. While Christians constitute the majority in countries like the Philippines, Christianity is largely a minority religion in the region. ${ }^{1}$ Christian groups in Asia are compelled to engage secular institutional structures, goals, and aspirations in order to negotiate a space for themselves in the nation-states they inhabit. These everyday struggles challenge understandings of Christian groups in the global south as operating independently of the state, phenomena that draw primarily from studies on Christian groups in Africa and Latin America and which have been used as evidence of an emerging Christendom that transcends the state. ${ }^{2}$

The Asian Christian experience is diverse and complex. While some Asian states like Singapore and the People's Republic of China are staunchly secular in orientation and largely see themselves as adopting a balanced approach in managing the different religious faiths operating within respective national boundaries, others such as Sri Lanka and Thailand incorporate religious myths to reinforce political legitimacy and religious elements into governing approaches, at times privileging one religious faith over the other. Christian responses to this uneven political terrain is varied. Some groups choose to work within state-sponsored frameworks while others actively manage the state through careful positioning and deliberate compartmentalisation of church activities. At times, Christian groups in Asia have also contested state goals and expectations. ${ }^{3}$ These struggles by Christian groups to engage nation-states are

1 Bautista and Lim (2009).

2 Jenkins (2011); Robert (2009); Senneh and Carpenter (2005).

3 Bautista and Lim (2009); Cannell (2005); Chong (2015); Lahiri (2005); Yip and Ainsworth (2015). 
further complicated by multiple intersecting and overlapping streams of missionary activities across Asia over several millennia. ${ }^{4}$ These historical engagements continue to shape the nature of interactions between Christianity and the state in contemporary Asia.

The essays collected within this special issue add to this discussion through a focus on citizenship. One strand of Christian theology conceives of the state as a secular institution that exists in parallel with the Church. Inhabiting this dual structure, Christian individuals regard themselves as anticipating the ultimate salvation, a form of sacred deliverance conceived of as entry into a divine kingdom. Adherents of this theological formulation generally commit to acts of piety that include following the divine authority of their Christian God and embodying the norms of religious and ethical behaviour such as praying regularly, tithing and contributing to the church in return for access to welfare, education resources, and sacramental services. ${ }^{5}$ At the same time, Christians accept the temporal authority of the secular state and mostly see themselves as honest, trustworthy, and law-abiding foreign residents living and working in a secular world. ${ }^{6}$ Co-operating with the secular state is accepted as necessary to accessing a superior religious kingdom. ${ }^{7}$ The fundamental message in this theological formulation of citizenship is that Christians are dual citizens ${ }^{8}$ seeking to inhabit the secular world in the present while anticipating future entry into a religious domain.

In contrast, secular conceptions of citizenship are decidedly this-worldly. People are thought to contribute to the national collective through public service, reproduction, and work. ${ }^{9}$ The fulfilment of these obligations accord individuals with rights to make claims on the nation-state. ${ }^{10}$ However, citizenship is not just a legal status that compels citizens to fulfil obligations and exercise rights. The way people see themselves as part of a national collective is shaped by the way they think of themselves religiously, ethnically, and racially, ${ }^{11}$ as well as through engagements with geopolitical dynamics. ${ }^{12}$ When people perform their rights and responsibilities to the nation-state, be it through voting, paying taxes, or championing issues of concern to wider society, they bring citizenship

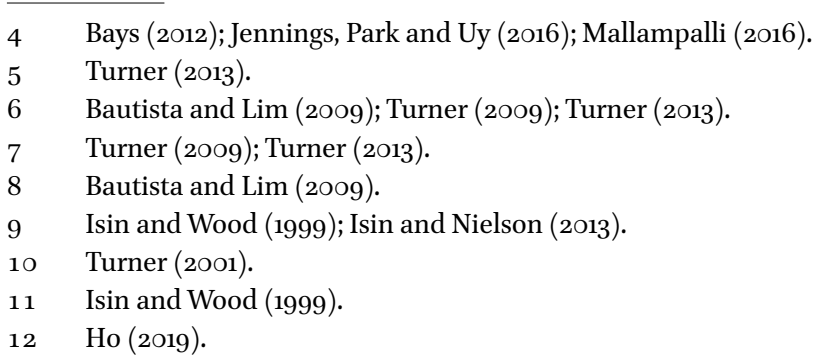


into being. ${ }^{13}$ The enactment of these individual or collective 'acts of citizenship' produces and transforms dominant understandings of citizenship within the nation-state. ${ }^{14}$

Scholars engaged in the social scientific study of religion have sought to bring these differing conceptualisations of what it means to be a part of a political collective together. Two approaches dominate this discussion. Bryan Turner proposes that membership to a religious group is a form of 'religious citizenship. ${ }^{15}$ As with secular forms of national belonging that emphasise obligations and entitlements, religious membership is attended by rights such as access to sacraments and contributions to the religious community like the paying of church taxes. While the worth of a citizen in the secular state is measured by their contributions to work, public service, and reproduction, ${ }^{16}$ the upstanding citizen in a religious community is assessed based on the extent to which they embody the religious habitus. ${ }^{17}$ In this approach, the secular and the religious are conceived as separate but conflicting spheres. Turner argues that, in modern secular societies, this relationship is entangled within institutional frameworks of rights and duties. ${ }^{18}$ Efforts by secular states to manage religious beliefs and practices have also created an asymmetrical relationship where religious structures, aspirations, and membership are subordinated to state-sponsored institutions, goals, and belonging. Conflict occurs when these different forms of membership compete for prominence in public life such as when religious practices are challenged by the secular state and its adherents and conversely, when religious groups negotiate state regulations governing their religious practices.

Prasenjit Duara ${ }^{19}$ posits a different approach. Like Turner, he acknowledges state tendencies to control religious ideas and practices, the potential of religious ideas to subvert state power, and the subordination of religion to secular ideals by modern secular societies. Departing from Turner, he turns his attention to the interactions between religion and secularism. Taking a historical approach, Duara argues that religious groups and individuals have harnessed secular political ideas like nationalism and used these notions to shape what it means to be a part of a religious community. Similarly, religious loyalty, myth,

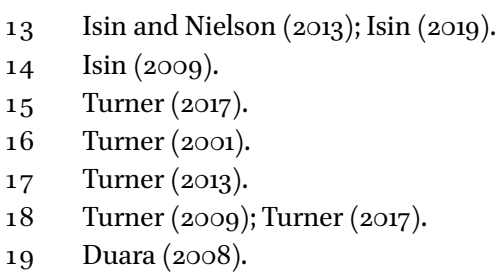


and rituals have provided valuable resources to secular states seeking to build a sense of belonging to a political entity. This 'traffic'20 of ideas and practices make and remake understandings of what it means to be a part of a secular state and a religious community. For Duara, accepting a division between religion and secularism obscures the ways in which these spheres mutually constitute and transform each other, interactions that not only produce particular types of citizens but also rupture existing connections between religious groups, society, and the state. The relationship between religion and citizenship in this conceptualisation is dynamic and transformative.

The essays collected in this special issue explore how a traffic of ideas and practices between the religious and the secular shape understandings of citizenship in Asia. Grounded in extensive ethnographic research, the articles examine how Christian groups in India, Sri Lanka, the Philippines, Malaysia, and Taiwan incorporate, resist, and negotiate understandings of what it means to be a citizen. Some of these contributions demonstrate how Christian missions, both in the past and in the present, constitute a form of social action that shapes understandings of citizenship in these Asian states. Others show how Christian groups negotiate nation-states grounded in non-Christian religious persuasions.

Sarbeswar Sahoo demonstrates how the Bhils, a marginalised tribal community in southern Rajasthan, construct new identities as 'Christian citizens' through Pentecostalism as a response to an ineffective state that has all but forgotten about them. He shows how Bhil experiences of conversion and attendance at church-run counselling sessions inculcate values of respect, equality, dignity, and compassion in individuals. These processes of learning to embody Christian ethics and morality lowered domestic violence and brought about greater gender equality in Bhil communities. Furthermore, by addressing the gaps within the state system, church-run social ministries transformed educational levels, health standards, and social development. Although Pentecostal missionaries, much like the Indian state, viewed the Bhils as primitive and needing civilising, their efforts supported this tribal community in learning how to build a better life. These transformative moral and behavioural changes enabled the Bhils to better align themselves to state imaginations of an ideal citizen. Moral and bodily disciplining through Pentecostalism, argues Sahoo, forms ethical subjects capable of contributing to the Indian state.

Bernardo Brown shifts our attention to another part of South Asia. He investigates how Catholic communities in Sri Lanka position themselves as a model 
minority in church-led efforts to de-escalate anti-Muslim sentiments in the wake of the deadly Easter bomb attacks in 2019. The Sri Lankan Catholic Church sought to mitigate the fallout of the event by aligning with the Sinhala nationalist stance while distancing itself from evangelical Christians. Contextualising the Catholic response within the political and religious realities of Sri Lanka, Brown shows how the church protected its congregation by positioning them as model citizens supportive of Sinhala nationalism. In a context where the state does not consider protection of minority rights its responsibility, religious minorities have to depend on themselves and the political acumen for their religious leadership to keep them safe.

A public debate about the reinstatement of capital punishment as part of President Duterte's campaign against criminality provides important insights into how Christian minorities in the Philippines are seeking to define what it means to be Filipino. Analysing media statements from evangelical and independent Christian lawmakers, Jayeel Cornelio and Prince Aldama observe that the approach embraced by these Christian figures is aggressive and disregards the plurality of Philippine society. Their sensitive reading of these public statements illuminate the ways in which minority Christian groups, together with the state, are shaping public discourse. Christian proclamations of the death penalty as divinely ordained not only validate the state's move to reinstate capital punishment but also makes a statement about how these Christian minorities think about what it means to be a part of the Philippine nation. This form of religious citizenship, argue Cornelio and Aldama, is one where every Filipino must be Christian.

In contrast to the assertive Christian stance in the Philippines, Shanthini Pillai's study of the Malaysian Catholic community underscores a dynamic interplay of cultural and religious elements in the shaping of what it means to be a part of a Muslim-dominated state. Conceiving of these cultural interactions as a form of 'synekism' (Soja 2000), Pillai suggests that the historical roots of Malaysian Catholic synekism lie in the activities of the Société des Missions étrangères de Paris (MEP) in the 19th century. Pillai connects these early missionary activities to how citizenship is practised by Malaysian Catholics in contemporary Malaysia through a rich analysis of how a tabernacle in the shape of a Malay house, the statue of Madonna and Child, as well as the use of Malay cultural symbols and the Malaysian national anthem are incorporated into religious practice. For Pillai, the melding together of ethnic cultural, national, and religious symbols emerges out of a long Catholic history of engagements between missionaries and different ethnic groups. These dynamic interactions created an ethno-religious space where it is possible to be a Malaysian Catholic in a Muslim-dominated nation-state. 
Shu-ling Yeh and Ying-cheng Chang examine how the Amis, the largest indigenous community in Taiwan, draw on their Catholic faith to preserve traditional cultural practices, perpetuate long-standing social structures and relationships, as well as deepen a sense of what it means to be a part of the island republic. Since the 19th century, successive governments have treated the Amis as marginalised citizens. This situation changed in 1987 when the Taiwanese government adopted multiculturalism as the primary form of governance. This shift in political priorities recognised indigenous cultures as an integral part of Taiwanese identity. The authors describe how the Amis practice what they refer to as 'tradition-in-Christianity' in this political context. They demonstrate how the Amis incorporate pre-Christian rituals like the ilisin and traditional social relationships encapsulated within the fraternal-paternal age-set organisation into Amis Catholic practices, thereby preserving and reinforcing their indigenous identity and culture. They also show the Amis strategically displaying their Christian faith to the Taiwanese public in order to assert a place for themselves in wider Taiwanese society. Drawing on ethnographic case studies of Amis Catholic practices, Yeh and Chang argue that conversion enabled this indigenous community to deepen what it means to be Amis, Catholic, and Taiwanese.

Taken together, the essays in this special journal issue take a step towards unravelling the entangled relationship between religion and citizenship. They move beyond an understanding of the religious and the secular as separate spheres by paying attention to the ways in which ideas and practices in these spheres interact with each other. They demonstrate how these engagements either constitute or transform dominant understandings of what it means to be part of a national collective across different political regimes and religious contexts in Asia. Furthermore, their attention to religious materiality and pedagogy, as well as social issues and political events, as objects of investigation suggest conceptual vehicles to untangle the traffic of ideas and practices that constitute the relationship between religion and citizenship. As all these essays have shown, religious adherents actively constitute themselves as citizens, crafting a religious form of belonging to the nation, when they engage in these acts of citizenship.

\section{Bibliography}

Bautista, Julius and Lim, Francis Khek Gee Lim, eds. (2009). Christianity and the State in Asia: Complicity and Conflict. London: Routledge.

Bays, Daniel. (2012). A New History of Christianity in China. Malden, M.A.: Blackwell. 
Cannell, Fenella. (2005). Immaterial Culture: "Idolatory" in the Lowland Philippines. In: Andrew Willford and Kenneth George, eds., Spirited Politics: Religion and Public Life in Contemporary Southeast Asia, Ithaca: Southeast Asia Program, Cornell University, pp. 159-184.

Chong, Terence. (2015). Megachurches in Singapore: The Faith of an Emergent Middle Class. Pacific Affairs 88(2), pp. 215-235.

Duara, Prasenjit. (2008). Religion and Citizenship in China and the Diaspora. In: Mayfair Mei-Hui Yang ed., Chinese Religiosities: Afflictions of Modernity and State Formation, Berkeley: University of California Press, pp. 43-64.

Ho, Elaine Lynn-Ee. (2019). Citizens in Motion: Emigration, Immigration, and Re-Migration across China's Borders. Stanford: Stanford University Press.

Isin, Engin. (2009). Citizenship in Flux. The Figure of the Activist Citizen. Subjectivity 29, pp. 367-388.

Isin, Engin. (2019). Doing Rights with Things: The Art of Becoming Citizens. In: Paula Hildebrandt, Kerstin Evert, Sibylle Peters, Mirjam Schaub, Kathrin Wildner, Gesa Ziemer, eds., Performing Citizenship: Bodies, Agencies, Limitations. Cham: Palgrave Macmillian, pp. $45^{-5} 5^{6}$.

Isin, Engin and Nielsen, Greg, eds. (2013). Acts of Citizenship. London: Zed Books.

Isin, Engin and Wood, Patricia. (1999). Citizenship and Identity. London: SAGE.

Jenkins, Philip. (2011). Next Christendom: The Coming of Global Christianity. Oxford: Oxford University Press.

Jennings, J. Nelson, Yong Kyu Park, and Antolin V. Uy. (2016). Korea, Japan, the Philippines, and Southeast Asia. In: Lamin Sanneh and Michael J McClymond, eds., The Wiley Blackwell Companion to World Christianity. Hoboken, N.J: Wiley Blackwell, pp. 561-574.

Lahiri, Smita. (2005). The Priestess and the Politician: Enunciating Filipino Cultural Nationalism through Mt Banahaw. In: Andrew Willford and Kenneth George, eds., Spirited Politics: Religion and Public Life in Contemporary Southeast Asia, Ithaca: Southeast Asia Program, Cornell University, pp. 23-43.

Mallampalli, Chandra. (2016). South Asia. In: Lamin Sanneh and Michael J McClymond, eds., The Wiley Blackwell Companion to World Christianity. Hoboken, N.J:Wiley Blackwell, pp. 535-545.

Robert, Dana. (2009). Christian Mission: How Christianity became a World Religion. Malden: Wiley-Blackwell.

Sanneh, Lamin, and Carpenter, Joel. (2005). The Changing Face of Christianity: Africa, the West, and the World. New York: Oxford University Press.

Soja, Edward W. (2000). Postmetropolis: Critical Studies of Cities and Regions. Oxford: Blackwell.

Turner, Bryan. (2001). The Erosion of Citizenship. British Journal of Sociology 52(2), pp. 189-209. 
Turner, Bryan. (2009). Evangelism, the State and Subjectivity. In: Julius Bautista, Francis Khek Gee Lim, eds., Christianity and the State in Asia: Complicity and Conflict, London: Routledge, pp. 18-35.

Turner, Bryan. (2013). Acts of Piety: The Political and the Religious, or a Tale of Two Cities. In: Engin Isin, Greg Nielson, eds., Acts of Citizenship, London: Zed Books, pp. $121-136$.

Turner, Bryan. (2017). Secular and Religious Citizenship. In: Ayelet Shachar, Rainer Bauböck, Irene Bloemraad, Maarten Vink, eds., The Oxford Hanbook of Citizenship, Oxford: Oxford University Press, pp. 478-499.

Yip, Jeaney and Ainsworth, Susan. (2015). “Do Business Till He Comes”: The Business of Housing God in Singapore Megachurches. Pacific Affairs 88(2), pp. 237-257. 